\title{
Hodgkin's Lymphoma - evaluation of patients submitted to Autologous transplantation of hematopoietic cells in the Hematology Service of the Hospital Walter Cantídio - Fortaleza, Brazil.
}

\author{
${ }^{1}$ Hematologist Physician. Head of the Service of Hematology, Bone-Marrow Transplant Unit and Cord Blood Bank \\ ${ }^{2}$ Resident Physician at $\mathrm{SH} / \mathrm{HUWC}$ \\ ${ }^{3}$ Physician at the Bone-Marrow Transplant Unit \\ ${ }^{4}$ Hematologist Physician. Professor of the Department of Internal Medicine of Faculdade de Medicina da UFC \\ 5 Physician at $\mathrm{SH} / \mathrm{HUWC}$ \\ ${ }^{6}$ Undergraduate Medical Student \\ Hematologist Physician. Professor of the Department of Internal Medicine of Faculdade de Medicina da UFC
}

Fernando Barroso Duarte ${ }^{1 *}$, Mabel Gomes de Brito Fernandes ${ }^{2}$, Jacques Kaufmann ${ }^{3}$, Karine Sampaio Nunes Barroso ${ }^{3}$, João Paulo de Vasconcelos Leitão ${ }^{3}$, Beatriz Stela Gomes de Souza Pitombeira Araujo ${ }^{3}$, Clara Maria Bastos Eloy da Costa ${ }^{4}$, Acy Teles Quixadá-medica ${ }^{5}$, Jacqueline de Souza Holanda ${ }^{5}$, Samuel Vasconcelos landim ${ }^{6}$, Maria Helena Pitombeira ${ }^{7}$

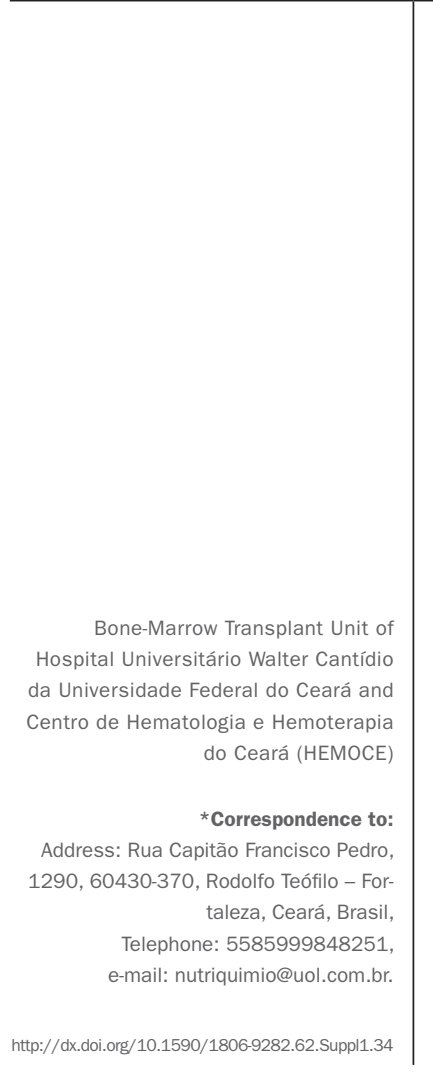

\section{SUMMARY}

The Autologous HSCT is an important alternative for refractory or recurrent HL patients in terms of survival and improved quality of life. This study analyzes the results of autologous BMT performed in HL patients in the Transplant Unit of the HUWC/ HEMOCE (Fortaleza - CE, Brazil). Fifty-two transplanted patients were studied from January 2009 to October 2015, among them, 30 men and 22 women, mean age of 28.2 years. All of them received GCS-F during the mobilization, in some cases associated with Vinorelbine or Plerixafor, with CD34 collection averaging $4.8 \mathrm{CD} 34 / \mathrm{kg}$. The conditioning was performed with BEAC, NEAM or BEAM and the grafting with an average of 10 days. The evaluation on D +100 showed: CR - 42 (82.7\%), PR - 08 $(13.5 \%)$ and $02(3.8 \%)$ deaths, three and six days after cell infusion. After the $\mathrm{D}+100$, 08 patients in CR showed HL recurrence from 06 to 36 months; 03 died and 05 are being treated with brentuximab; among the 08 patients in PR, 01 died due to HL activity, 04 months after BMT and 07 patients are undergoing treatment. The final evaluation of HL transplant patients showed an OS of $88.5 \%$ and a DFS of $61.5 \%$ in 6 years, with OS of the chemosensitive patients of $81 \%$ and of the chemoresistant ones, of $72.6 \%$. It is possible to conclude that the Autologous HSCT has shown to be an excellent rescue therapy regarding tolerance, as well as the overall survival.

Keywords: Hematopoietic Stem Cell Transplantation; Hodgkin's lymphoma; Autologous transplantation.

\section{INTRODUCTION}

Hodgkin's lymphoma (HL) is a B lymphoid neoplasia, with a higher incidence in young adults, curable in up to $80 \%$ of cases. Advancements in HL therapy have been documented since the introduction of combination chemotherapy protocols and changes in irradiation strategies. ${ }^{1,2,3}$ Despite these advancements, approximately $10 \%$ of refractory patients and 20 to $25 \%$ with lymphoma recurrence should be carefully re-evaluated for a second attempt at remission. Several studies have shown that autologous hematopoietic stem cell transplantation (HSCT) is one of the most important alternatives for such patients in terms of survival and improved quality of life. The allogeneic transplant does not have a well-defined role in this new treatment strategy. ${ }^{4}$ More recent studies have shown the importance of haploidentical transplantation in the rescue of refractory HL patients nonresponsive to autologous transplantation. ${ }^{5}$

The objective of this study is to analyze the results of autologous BMT performed in LH patients at the Transplant Unit of SH of HUWC/HEMOCE.

\section{Métodos}

Patients originating from the state of Ceará and treated in several medical services are referred to the 
Hematology Service, where they are seen in the PreTransplantation Outpatient Clinic for reassessment of BMT indication. Patients are referred with their respective medical records from the original service, containing the biopsy diagnosis report, immunohistochemistry, chemotherapy and radiotherapy protocols performed, date of recurrence or whether the patient is refractory to treatment. With these first recommendations the patient is enrolled in the BMT waiting listing, after which medical history and complete physical examination, hematological, biochemical and imaging evaluations are performed. A dental assessment, consultations with a nutritionist and psychologist are also requested.

The results are then analyzed for the patient to be referred to the transplantation team to schedule the mobilization and collection of hematopoietic stem cells and subsequent hospitalization for cell conditioning and infusion.

\section{ResULTS}

A total of 54 patients were submitted to autologous transplantation from January 2009 to April 2016, of which 31 were men, aged between 17 and 63 years (mean 28.1 years) and 23 women, aged 16 to 51 years (mean 28.2 years); 21 were originally from Fortaleza and 33 from other cities in the state of Ceará. The present analysis includes 52 patients treated up to October 2015. Clinical and epidemiological characteristics are shown in Chart 1.

Regarding the first treatment, all patients received the ABVD polydrug regimen (Adriamycin, bleomycin, vinblastine, dacarbazine), of which 16 underwent associated field radiotherapy. In response, 21 patients went into complete remission, 16 into partial remission and $15 \mathrm{did}$ not respond. Of the 21 in $\mathrm{CR}$, recurrence ranged from 5 months to 14 years, whereas two had HL recurrence after less than 6 months, seven between 6 and 12 months and twelve more than 12 months (Chart 2).

As the second treatment due to recurrence or no response/refractory patient, $35(62.5 \%)$ patients received the ICE regimen 12 (20.8\%) ICE associated to another polychemotherapy regimen, five received DHAP, two received ESHAP and one received ABVD. The analysis of the response at this step of treatment showed that 27 (51.9\%) achieved CR, whereas 25 (48.1\%) had PR.

All patients received GCS-F during mobilization, and 35 were mobilized only with G-CSF, 15 with Vinorelbine and G-CSF, two with Plerixafor and G-CSF. CD34 collection ranged from 2.03 to $18.39 \times 10^{6} \mathrm{CD} 34$ cells/kilogram, with a mean of 4.8. The waiting time until transplantation ranged from 26 to 274 days, with a mean of 86.3 days.
Conditioning was performed with BEAC in 34 (65.4\%), NEAM in $13(25.0 \%)$ and BEAM in five (9.6\%) patients. Grafting varied from 7 to 15 days, occurring in 19 (36.6\%) patients in less than 10 days, in $28(50 \%)$ between 10 and 12 days, in $3(5.7 \%)$ more than 12 days and 2 (3.8\%) showed no grafting.

The post-BMT results up to $\mathrm{D}+100$ showed: CR - 42 (82.7\%), PR - 8 (13.5\%) and 2 (3.8\%) deaths, which occurred 3 and 6 days after cell infusion. After D+100, 8 patients in CR showed HL recurrence between 6 and 36 months; 3 died and 5 are being treated with brentuximab; of the 8 patients in PR, 1 died due to HL activity four months after the BMT and 7 are undergoing treatment (2 with allogeneic transplant indication).

Charts 3 and 4 show the results considering patient clinical status (CR and PR) before BMT, the assessment on D+100 and the last report (May 2016).

\begin{tabular}{|c|c|c|}
\hline Characteristics & $\mathrm{N}$ & $\%$ \\
\hline \multicolumn{3}{|l|}{ Age at diagnosis } \\
\hline mean (Range) & \multicolumn{2}{|c|}{16 a 51} \\
\hline$<25$ & 21 & 40.4 \\
\hline $25-44$ & 29 & 55.8 \\
\hline$>44$ & 02 & 3.8 \\
\hline \multicolumn{3}{|l|}{ Origin } \\
\hline Fortaleza & 21 & 40.4 \\
\hline Other cities & 31 & 69.6 \\
\hline \multicolumn{3}{|l|}{ Gender } \\
\hline Male & 30 & 57.6 \\
\hline Female & 22 & 43.4 \\
\hline \multicolumn{3}{|l|}{ Histological types } \\
\hline LP & 01 & 1.9 \\
\hline$M C$ & 01 & 1.9 \\
\hline NS & 46 & 88.6 \\
\hline LD & 02 & 3.8 \\
\hline $\mathrm{NI}$ & 02 & 3.8 \\
\hline \multicolumn{3}{|c|}{ Initial clinical staging (Ann Arbor) } \\
\hline $1+I I$ & 29 & 55.8 \\
\hline III + IV & 19 & 36.6 \\
\hline $\mathrm{NI}$ & 04 & 7.6 \\
\hline \multicolumn{3}{|l|}{ Constitutional symptoms } \\
\hline A & 16 & 30.8 \\
\hline $\mathrm{B}$ & 34 & 65.4 \\
\hline $\mathrm{NI}$ & 02 & 3.8 \\
\hline \multicolumn{3}{|l|}{ Immunophenotyping } \\
\hline CD30+ CD15+ CD20+ & 33 & 63.5 \\
\hline CD30+ CD15neg CD20+ & 02 & 3.8 \\
\hline CD30+ CD15+ CD20neg & 10 & 19.3 \\
\hline $\mathrm{NI}$ & 07 & 13.4 \\
\hline \multicolumn{3}{|l|}{ First treatment } \\
\hline ABVD & 36 & 69.3 \\
\hline ABVD + radiotherapy & 16 & 30.7 \\
\hline
\end{tabular}


Seven years after the first and seven months after the last evaluated BMT (October 2015), the following results were observed: CR - $32(61.6 \%)$ patients, PR and treatment $-14(26.9 \%)$ and $6(11.5 \%)$ deaths. The overall survival, disease-free curves and chemosensitive and chemoresistant cases are shown in graphs 1, 2, 3 and 4.

\section{Discussion}

The Hematological Service of HUWC/UFC/ HEMOCE has 50 years of experience with HL and 1045 followed cases. Eight years ago, a Bone Marrow Transplant Unit was implemented, a procedure that brought a new dimension to patients with refractory disease.

The prognosis of Hodgkin's lymphoma has improved considerably with the new chemotherapy regimens and advancements in radiotherapy techniques, allowing young patients to have a disease-free survival rate of approximately $80 \%$ and even achieving the cure. ${ }^{2,3,6}$ Currently, it is worth mentioning the new forms of treatment, including targeted therapy and the possibility of bone marrow trans-

CHART 2. Distribution of patients according to the responses at several stages of transplantation

Characteristics

$\mathrm{N} \quad \%$

Response to first treatment

\begin{tabular}{|c|c|c|}
\hline Complete remission & 21 & 40.4 \\
\hline Partial remission & 15 & 28.8 \\
\hline Non-responder/Refractory & 16 & 30.8 \\
\hline \multicolumn{3}{|c|}{ Recurrence (after the first CR - 21 patients) } \\
\hline$<6$ months & 02 & 9.5 \\
\hline $6-12$ months & 09 & 42.9 \\
\hline$>12$ months & 10 & 47.6 \\
\hline \multicolumn{3}{|c|}{ Response to the second treatment (Pré TMO) } \\
\hline Complete remission & 26 & 50.0 \\
\hline Partial remission & 26 & 50.0 \\
\hline \multicolumn{3}{|l|}{ Mobilization } \\
\hline GCS-F & 35 & 67.3 \\
\hline Plerixafor+GCS-F & 02 & 3.8 \\
\hline Vinorelbine+GCSF & 15 & 28.8 \\
\hline \multicolumn{3}{|l|}{ Conditioning } \\
\hline BEAC & 34 & 65.4 \\
\hline BEAM & 05 & 9.6 \\
\hline NEAM & 13 & 25.0 \\
\hline \multicolumn{3}{|l|}{ Grafting (days) } \\
\hline Variation & \multicolumn{2}{|c|}{$07-15$} \\
\hline$<10$ days & 18 & 34.7 \\
\hline $10-12$ days & 29 & 55.8 \\
\hline$>12$ days & 03 & 5.7 \\
\hline Grafting failure & 02 & 3.8 \\
\hline \multicolumn{3}{|l|}{ Status pós TMO (D+100) } \\
\hline Complete remission & 42 & 80.9 \\
\hline Partial remission & 08 & 15.3 \\
\hline Deaths & 02 & 3.8 \\
\hline
\end{tabular}

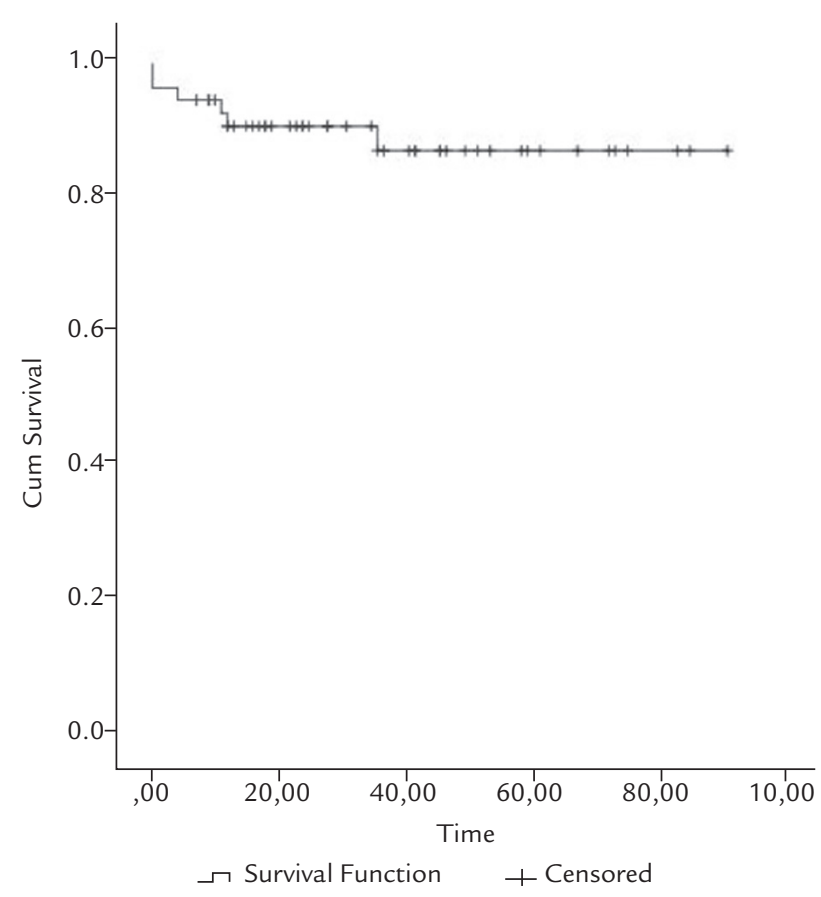

GRAPH 1. Overall survival of 52 patients with Hodgkin's lymphoma submitted to autologous bone marrow transplantation (2009-2015)

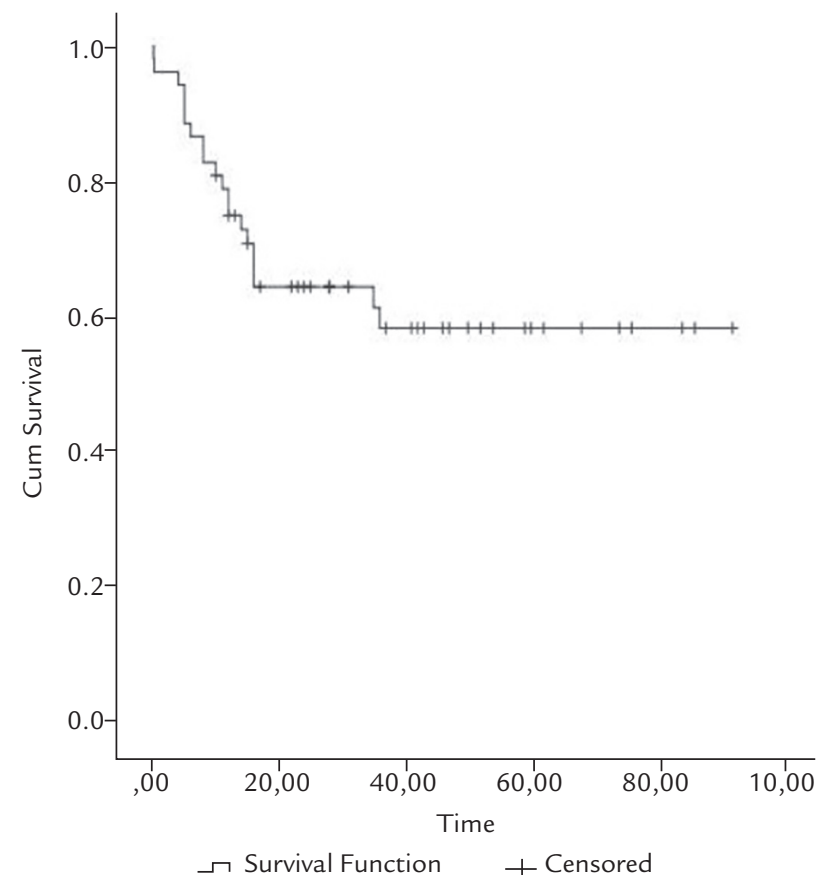

GRAPH 2. Disease-free survival of 52 patients with Hodgkin's lymphoma submitted to autologous bone marrow transplantation (2009-2015) 
plant indication not only in young patients, but also in those at older age groups..$^{7,8,9,10,11,12}$

The present analysis of transplanted patients at UTMO/HUWC/UFC shows a young population (mean age of 28 years), with a predominance of localized disease $(\mathrm{I}+\mathrm{II})$, mostly $\mathrm{B}$, initially treated with standard regimen (ABVD) and who did not respond or had recurrence,

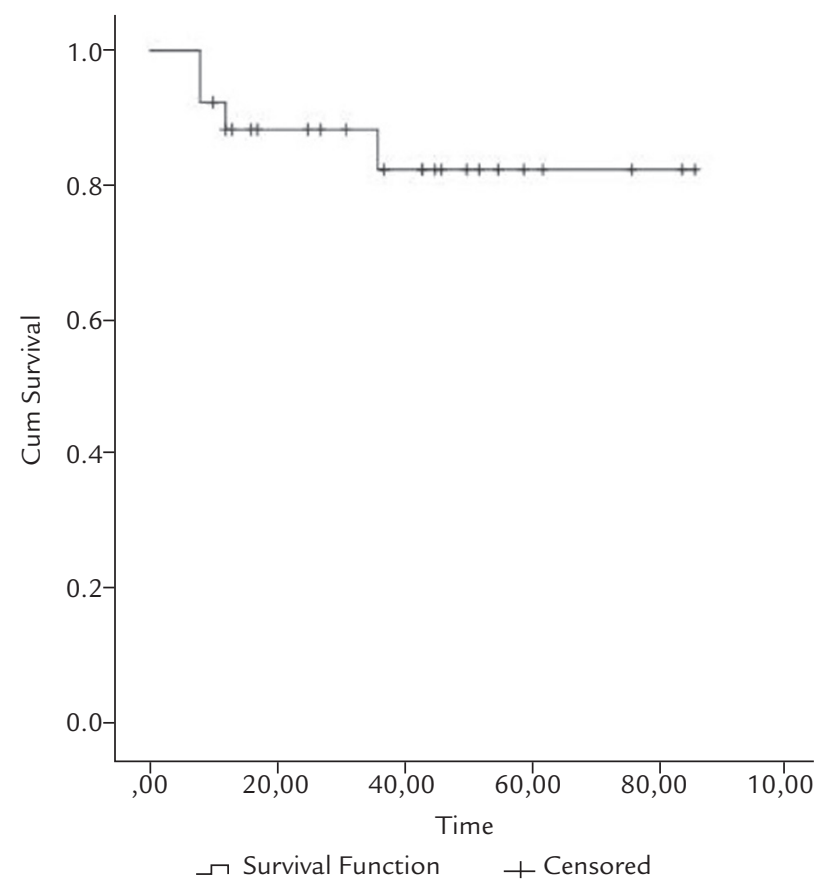

GRAPH 3. Survival of 26 chemosensitive patients with Hodgkin's lymphoma submitted to autologous bone marrow transplantation (2009-2015) becoming candidates for a new treatment regimen and the possibility of BMT indication. However, $50.0 \%$ of them came to transplantation in partial remission of the lymphoma, showing much lower results when considering the patient coming to the BMT in complete remission $(64.7 \%$ vs. $35.3 \%$ ). These data show the importance of trying to perform the transplant with the patient in the best possible

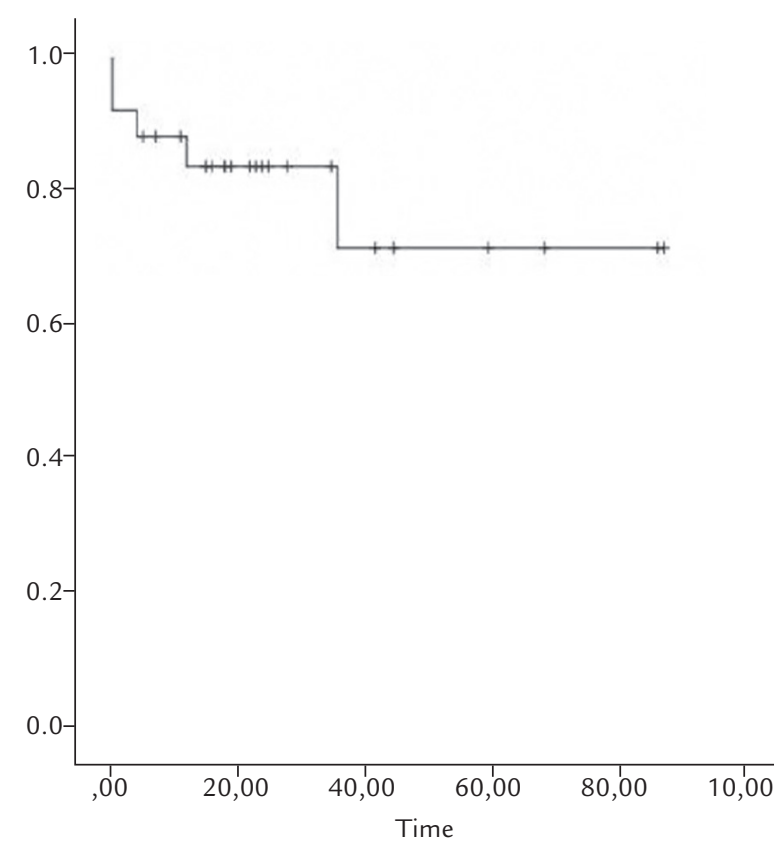

GRAPH 4. Overall survival of 26 chemoresistant patients with Hodgkin's lymphoma submitted to autologous bone marrow transplantation (2009-2015)

CHART 3. Distribution of patients according to the clinical criteria and the evolution of pre-BMT to the latest report (May 2016)

\begin{tabular}{llll} 
& RESULTS & & Current \\
\cline { 2 - 4 } Criteria & PRE-BMT & $\mathrm{N} \%$ \\
\hline Complete remission & $\mathrm{N} \%$ & $\mathrm{~N} \%$ & $34(65.4)$ \\
\hline Partial remission & $27(51.9)$ & $42(80.9)$ & $14(29.6)$ \\
\hline Deaths & $25(48.1)$ & $08(15.3 \%)$ & $04(7.7)$ \\
\hline Total & - & $02(3.8)$ & $52(100.0)$ \\
\hline
\end{tabular}

\section{CHART 4. Distribution of patients according to the complete remission criteria in the pre-BMT, on D +100 and the latest} report (May 2016)

\begin{tabular}{|c|c|c|c|c|c|c|}
\hline Critérios & \multicolumn{2}{|c|}{$\begin{array}{l}\text { PRE-BMT } \\
\text { Status de } \\
\text { entrada N \% }\end{array}$} & \multicolumn{2}{|c|}{$\begin{array}{l}\mathrm{D}+100 \\
\text { Complete remission } \\
\mathrm{N} \%\end{array}$} & \multicolumn{2}{|c|}{$\begin{array}{l}\text { Latest report } \\
\text { Complete remission } \\
\mathrm{N} \%\end{array}$} \\
\hline Complete remission & 27 & 51.9 & 25 & 59.6 & 22 & 64.7 \\
\hline Partial remission & 25 & 48.1 & 17 & 40.4 & 12 & 35.3 \\
\hline Total & 52 & 100.0 & 42 & 100.0 & 34 & 100.0 \\
\hline
\end{tabular}


conditions of absence of disease activity, with chemoresistance being identified as worsening factor of response to $\mathrm{BMT}^{13}$ (Chart 3).

The conditioning with the BEAC regimen showed to be very effective, as well as the NEAM (91.1\% vs. $84.6 \%)$ regarding the achievement of $\mathrm{CR}$ in patients evaluated at the level of $\mathrm{D}+100$. Some conditioning regimens suggest adding bortezomib to other drugs, but there was no significant difference in the outcome. ${ }^{14}$

The final evaluation of the transplanted HL patients showed an overall survival rate of $88.5 \%$ and $61.5 \%$ disease-free survival at six years, with an overall survival of chemosensitive patients of $81 \%$ and $72.6 \%$ in chemoresistant ones, results comparable to other transplant centers 15,16 and even to data from the Center for International Blood \& Marrow Transplant Research, or CIBMTR. ${ }^{17}$

It is possible to conclude that autologous HSCT emerges an excellent rescue therapy regarding tolerance and overall survival.

\section{Resumo}

Linfoma de Hodgkin - avaliação dos pacientes submetidos a transplante autólogo de células hematopoéticas no Serviço de Hematologia do HUWC

O TCTH autólogo é uma importante alternativa para os pacientes de LH refratários ou recidivados, em termos de sobrevida e melhora da qualidade de vida. O presente trabalho analisa os resultados do TMO autólogo realizado em pacientes de LH na Unidade de Transplante do SH do HUWC/HEMOCE. Foram estudados 52 pacientes submetidos ao TMO de janeiro de 2009 a outubro de 2015, sendo 30 homens e 22 mulheres, média de idade de 28,2 anos. Todos receberam GCS-F na mobilização, em alguns casos associados a Vinorelbine ou a Plerixafor e coleta de CD34 com média de 4,8CD34/kilo. O condicionamento foi realizado com BEAC, NEAM ou BEAM e a enxertia com média de 10 dias. A avaliação no D+100 mostrou: RC - 42 $(82,7 \%), \mathrm{RP}-08(13,5 \%)$ e 02 (3,8\%) óbitos ocorridos 3 e 6 dias após a infusão das células. Após o D+100, 08 pacientes em RC apresentaram recidiva do LH entre 6 e 36 meses; 3 foram a óbito e 5 estão em tratamento com brentuximabe; os 8 pacientes em RP, 1 faleceu por atividade do LH, 4 meses após o TMO e 7 estão em tratamento. A avaliação final dos pacientes de LH transplantados mostrou uma SG de 88,5\% e SLD de 61,5\% em 6 anos, SG dos pacientes quimiossensiveis de $81 \%$ e dos quimioresistentes de $72,6 \%$.

É possível concluir que o TCTH Autólogo se coloca como excelente terapia de resgate em relação à tolerância, bem como na sobrevida global.

Palavras-chaves: Transplante de células-tronco hematopoiéticas;

\section{References}

1. DeVita VT Jr, Serpick AA, Carbone PP. Combination chemotherapy in the treatment of advanced Hodgkin's disease. Ann Intern Med. 1970;73(6):881-95

2. Engert A, Ballova V, Haverkamp H, Pfistner B, Josting A, Duhmke E, et al. Hodgkin's lymphoma in elderly patients: a comprehensive retrospective analysis from the German Hodgkin`s Study Group. J Clin Oncol. 2005;23(22):5052-5060

3. Koshy M, Rich SE, Mahmood U, Kwok Y. The declining utilization of radiation therapy in stage I and II Hodgkin's disease and its impact on survival and secondary malignancies. Int J Radiat Oncol Biol Phys. 2010;78(3):S65-S6.

4. Rashidi A, Ebadi M, Cashen AF. Allogenic hematopoitec stem cell transplantation in Hodgkin lymphoma: a systematic review and meta-analysis. Bone Marrow Transplant. 2016;51(4):521-8

5. Fedele R, Martini M, Recchia AG, Irrere G, Gentile M, Morabito F. Clinical options in relapsed or refractory Hodgkin Lymphoma: An updated review. J Immunol Res. 2015; 2015:968212.

6. Brusamolino E, Bacigalupo A, Barosi G, Biti G, Gobbi PG, Levis A, et al. Classical Hodgkin's lymphoma in adults: Guidelines of the Italian Society of Hematology, the Italian Society of Experimental Hematology, and the Italian Group for Bone Marrow Transplantation on initial work-up, management, and follow-up. Haematologica. 2009;94(4):550-62.

7. Puig N, Pintilie M, Seshadri T, Al-Farsi K, Franke N, Keating A, et al. Highdose chemotherapy and auto-SCT in elderly patients with Hodgkin's lymphoma. Bone Marrow Transplant. 2011;46(10):1339-44.

8. Boll B, Bredenfeld H, Gorgen H, Halbsguth T, Elch HT, Soekler M. Phase 2 study of PVAG (prednisone, vinblastine, doxorubicin, gemcitabine) in elderly patients with early unfavorable or advanced stage Hodgkin lymphoma. Blood. 2011;118(24):6292-8.

9. Canellos GP, Rosenberg SA, Friedberg JW, Lister TA, DeVita VT Jr. Treatment of Hodgkin lymphoma: a 50-Year perspective. J Clin Oncol. 2014;32(3):163-8

10. Forero-Torres A, Holkova B, Goldshmidt J, Chen R, Olsen G, Boccia RV, et al. Phase 2 study of fronline brentuximab vedotin monotherapy in Hodgkin lymphoma patients aged 60 years and older. Blood. 2015;126(26):2798-804

11. Ansell SM. Novel agents in the therapy of Hodgkin lymphoma. N Engl J Med. 2015;372(4):311-9.

12. Musso M, Messina G, Di Renzo N, Di Carlo P, Vitolo U,Scalone R, et al. Improved outcome of patients with relapsed/refractory Hodgkin lymphoma with a new fotemustine-based high-dose chemotherapy regimen. Br J Haematol. 2016;172(1):111-21.

13. Gerrie AS, Power MM, Shepherd JD, Savage KJ, Sehn LH, Connors JM. Chemoresistance can be overcome with high-dose chemotherapy and autologous stem-cell transplantation for relapsed and refractory Hodgkin lymphoma. Ann Oncol. 2014; 25(11):2218-23.

14. Balzarotti M, Brusamolino E, Angelucci E, Carella AM, Vitolo U, et al. B-IGEV (bortezomib plus IGEV) versus IGEV before high-dose chemotherapy followed by autologous stem cell transplantation in relapsed or refractory Hodgkin lymphoma: a randomized, phase II trial of the Fondazione Italiana Linfomi (FIL). Leuk Lymphoma. 2016;15:1-7.

15. Ramirez P, Ocqueteau M, Rodriguez A, Garcia MJ, Sarmiento M, et al. Outcomes in relapsed Hodgkin`s lymphoma treated with autologous and allogenic hematopoietic cell transplantation at the Pontificia Universidad Católica de Chile. Rev Bras Hematol Hemoter. 2015;37(3):184-9.

16. Kako S, Izutsu K, Kato K, Kim SW, Mori T, et al. The role of hematopoietic stem cell transplantation for relapsed and refractory Hodgkin lymphoma. Am J Hematol. 2014;90(2):132-8.

17. Center for International Blood Marrow Transplant Research. [cited 2016 Jun 26]. Available from: http://www.cibmtr.org. 